\title{
"A noite dos desesperados": motim no Presídio Central em Porto Aleore ${ }^{1}$
}

Cláudio Pereira Elmir

\begin{abstract}
Resumo. Ao descrever a intensa cobertura jornalística realizada sobre um motim ocorrido em Porto Alegre em julho de 1994, o trabalho pretende discutir as contradições e ambigüidades que constituem o discurso sobre o crime e demonstrar as relações desiguais que são estabelecidas entre criminosos, policiais, deputados, elites, jornalistas, o poder executivo estadual, as vítimas e a cidade. Em suma, o artigo intenta realizar a compreensão da lógica que preside a relação entre uma manifestação criminal e a sua veiculação no jornalismo impresso; fugindo esta da mera descrição informativa dos fatos, na medida em que a subjetividade é uma das principais características a regular a construção do texto jornalístico.
\end{abstract}

Palavras-chave: Porto Alegre. Presídio Central. Motim. Cobertura jornalística. Jornal Zero Hora.

* Professor da UNISINOS. Doutor em História pela UFRGS.

Anos 90, Porto Alegre, v. 12, n. 21/22, p.535-553, jan./dez. 2005 
"A noite dos desesperados": motim no Presídio Central em Porto Alegre

O eficaz desempenho da imprensa no episódio que teve por desfecho a queda de Fernando Collor acabou por conferir proporcões epidêmicas a um lastimável desvio de conduta. Afetados pela "síndrome de Clark Kent", bandos de jornalistas se julgaram dotados de superpoderes que lhes permitiram encarnar, simultaneamente, quatro papéis: o detetive infalivel, o delegado durão, o promotor que só acusa e o juiz que invariavelmente condena.

Augusto Nunes (out. 1994).

No meio da tarde do dia 7 de julho de 1994, teve início um motim no Presídio Central de Porto Alegre, cuja repercussão na imprensa local talvez tenha sido a maior entre os acontecimentos envolvendo o sistema penitenciário gaúcho. Nove detentos fizeram 24 reféns, sendo estes funcionários da casa prisional localizada num bairro de periferia - Partenon - da zona leste da cidade. Os sublevados exigiam, além da sua libertação, a soltura de 2 outros presos que cumpriam pena em uma penitenciária de alta segurança numa cidade nas proximidades da capital. Foi constituída uma comissão para negociar com os presos, formada por representantes dos poderes executivo, legislativo e judiciário do estado, aos quais foi dada autonomia para deliberar uma solução para o levante. Após muitas horas de negociação e avaliada a impossibilidade de uma saída de força - a invasão do local - sem a perspectiva de muitas vítimas fatais, no entendimento do comando da Brigada Militar, a comissão negociadora resolve aceder à fuga dos presidiários com a promessa de não persegui-los até o momento em que estes soltassem os reféns que levariam consigo. São oferecidos três carros para os detentos e estes fogem na noite do dia 8, sendo imediatamente perseguidos pela Polícia Civil nas ruas da cidade, antes de os reféns serem libertados.

Este é apenas um pedaço de uma história que envolve criminosos, policiais, deputados, juizes, jornalistas, vítimas e a cidade. Esta história foi resumida por mim de maneira tal que é preciso desconfiar da ausência de complexidade. Ao mesmo tempo, não há como contar uma história, um acontecimento ou um evento sem cometer, em alguma medida, o pecado da simplificação.

Anos 90, Porto Alegre, v. 12, n. 21/22, p.535-553, jan./dez. 2005 
Mesmo que este acontecimento tenha sido contemporâneo ao meu tempo e ao meu espaço de vida num sentido mais amplo, não fui testemunha ocular da sua realização, tendo reconstruído um momento desse acontecimento a partir daquilo que outras pessoas viram, ouviram, disseram ou escreveram. Neste sentido, o meu primeiro parágrafo é síntese incompleta de opinião e não o resumo exato da verdade. Penso que é imprescindível reconhecer o caráter parcial da minha narrativa para que possa tentar refletir sobre a incompletude, o juízo de valor e a ambigüidade que podemos per-

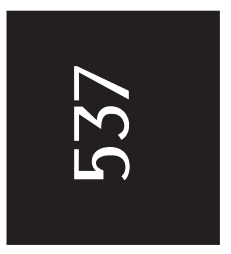
ceber nas narrativas alheias. ${ }^{2}$

Quero simplesmente comentar alguns aspectos sobre a forma como se realizou a cobertura jornalística desse evento, especialmente por meio da mídia impressa. Em outras palavras, quero tentar compreender como se estabelece a relação, nesse caso específico, entre uma manifestação criminal e a sua veiculação no jornalismo impresso. É o discurso sobre o crime o objeto de minha leitura agora.

Para tanto, irei me valer especialmente do jornal Zero Hora, cuja cobertura jornalística desse evento extrapolou os limites normalmente dedicados aos assuntos da Polícia - as últimas páginas do jornal, geralmente 3 ou 4, imediatamente antes do Esporte. $\mathrm{O}$ assunto mereceu algumas Reportagens Especiais, editoriais do jornal, editoriais internos e editoriais na contracapa do jornal, assinados pelo então Diretor de Redação, jornalista Augusto Nunes, pesquisa de opinião veiculada pelo jornal, publicação de cerca de 40 cartas de leitores em coluna específica, diretamente relacionadas com o motim, entrevistas feitas com reféns e com o "líder" dos presos, charges. Enfim, posso dizer que durante o mês de julho de 1994 as notícias envolvendo a rebelião do Presídio Central de Porto Alegre e os seus desdobramentos em termos de caçadas da polícia, mortes, capturas, debate sobre o sistema penitenciário como um todo, assumiram a centralidade entre as preocupações editoriais do periódico. 
"A noite dos desesperados": motim no Presídio Central em Porto Alegre

Meu interesse central não reside no entendimento da motivação que leva um jornal a cobrir de maneira tão intensa um evento como esse, ${ }^{3}$ mas, como já afirmei anteriormente, na demonstração de que as matérias envolvendo essa questão comportam um grau de opinião em que a subjetividade do articulista ajuda a recompor o "fato criminoso" nas linhas que escreve, produzindo, muitas vezes, uma percepção particular, mesmo que tente universalizá-la em seu discurso como o sentimento da sociedade. Exemplo claro desse tipo de abordagem é a matéria intitulada $O$ terror chegou com o frio, na qual lemos a maneira particular que o redator utiliza para narrar a fuga dos detentos:

O dia mais gelado do ano não parecia prenunciar a iminência da noite mais assustadora da história de Porto Alegre, sobressaltada por uma sucessão de horrores que atravessaria a madrugada de sexta-feira para sábado. Durante quase 10 horas, o som de tiros e sirenes, de gritos e ameaças, de desespero, morte e dor ecoou pela cidade. Dos descampados nos arredores do Shopping Center Iguatemi ao hall de entrada do hotel mais estrelado da capital gaúcha, dos barracos da Lomba do Pinheiro aos casarões do Moinhos de Vento, das imediações do Country Club ao Parque da Redenção, Porto Alegre viu-se envolta num clima de paranóia, angústia e terror circunscrito aos portões do Presídio Central até o momento em que o governo resolveu agir. (Zero Hora, 10.07.1994, p.4).

As cinco fotos reproduzidas na página ao lado ajudam a compor o quadro tenebroso feito pelo redator. O editorial do jornal critica "[...] o atendimento das exigências dos delinqüentes sem que fossem esgotadas todas as possibilidades de mantê-los na cadeia" (Zero Hora, 10.07.1994, p. 18), ao mesmo tempo em que alerta sobre a falta de homogeneidade nas decisões entre a Polícia Civil e a Brigada Militar. É neste mesmo exemplar que, na contracapa, o diretor de redação de Zero Hora assina um outro editorial, 
cujo título $A$ incompetência e o apocalipse, faz prever a busca do impacto que move o texto:

Durante 30 horas, o inferno reproduzido pelo maior motim da história do Rio Grande do Sul teve como fronteiras os muros do Presídio Central, [...] ao expandir as divisas do inferno até os limites do perímetro urbano de Porto Alegre, reduziu virtualmente todos os seus habitantes a involuntários passageiros da agonia. O apocalíptico 8 de julho submeteu Porto Alegre a uma experiência incompa-

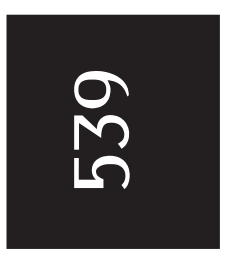
rável: pela primeira vez na História, a população inteira de uma grande cidade foi colocada na alça de mira de presos amotinados, todos bandidos perigosíssimos, graças à incompetência e à irresponsabilidade de homens supostamente responsáveis pela segurança dos cidadãos. (Zero Hora, 10.07.1994, p.56).

Editoriais expressam opinião, seja do veículo de comunicação - quando não assinados -, seja de articulistas - quando nominados. Contudo, o texto acima reproduzido é um exemplo evidente de opinião sobre uma questão premente e, podemos dizer, mal resolvida, cujo objetivo último é estabelecer um julgamento. O discurso elaborado por Augusto Nunes constrói culpados e vítimas ou "sujeitos ativos" e "sujeitos passivos" do crime, para utilizar a linguagem jurídica (Jesus, 1991, p.147-8, 153-8), representados estes, respectivamente, pelo Estado e seus prepostos - especialmente o Executivo Estadual e a Polícia Civil - e a sociedade porto-alegrense. ${ }^{4}$ Ao questionar a decisão tomada de aquiescer com a fuga dos rebelados, o jornalista também deslegitima a autoridade que o governador atribuiu à comissão negociadora, imputando a esta uma atitude pouco refletida. É preciso dar-se conta, porém, que o editorial, ao expressar a opinião do redator, realiza ao mesmo tempo a sentença sobre uma posição com a qual não concorda, atribuindo a si o papel de juiz, e julgando com muito pouco comedimento. 
"A noite dos desesperados": motim no Presídio Central em Porto Alegre

Se analisarmos o tratamento que outro jornal diário da cidade utiliza para enfocar o resultado do motim, verificaremos a distinção de conclusões. O Correio do Povo, realizando uma cobertura jornalística bem mais simples em termos da utilização de recursos humanos e materiais, assume uma posição diferente daquela de Zero Hora. ${ }^{5}$ É interessante observar que aquele jornal irá se pronunciar sobre o motim somente na terça-feira, quando a rebelião fora resolvida no sábado. Em editorial intitulado $A$ fragilidade do sistema penitenciário, podemos ler:

Criticar as decisões tomadas, depois do fato consumado, é fácil. O difícil é, sob forte tensão e quando vidas humanas estão em risco, a autoridade avaliar a extensão das conseqüências de sua ação. E foi, de fato, o que aconteceu. Com a melhor das intenções, a comissão negociadora liberou os amotinados para a fuga e igualmente com a melhor das intenções a Polícia Civil saiu na perseguição. (Correio do Povo, 12.07.1994, p.4).

Parece que aqui temos um outro extremo. Não fosse um editorial, poderíamos julgar estar lendo a coluna de um humorista que ironiza a situação. Neste caso, não temos uma opinião explícita do jornal. ${ }^{6}$ Contudo, não deixa de existir um juízo formulado sobre a atitude dos negociadores e da polícia; só que agora, positivo. Ao concordar com a boa intenção de ambos, o jornal se exime de apontar possíveis erros, criando uma ambigüidade no seu discurso. Principalmente se levarmos em conta que existe uma incompatibilidade entre as posições assumidas pelos sujeitos evocados no editorial.

É óbvio que muitas vezes as posições assumidas num mesmo jornal sobre uma mesma questão podem ser absolutamente distintas entre seus redatores. O artigo do jornalista Paulo Sant'Anna, Efeito esperado, na sua coluna diária da última folha do jornal, revela esta constatação ao dizer:

Anos 90, Porto Alegre, v. 12, n. 21/22, p.535-553, jan./dez. 2005 
Nós agora estamos abismados com a noite e os dias de horror vividos pela população de Porto Alegre. Pois então que se saiba e fique bem claro que os presos gaúchos vivem esse clima de medo e brutalidade todos os dias, há mais de 50 anos. Lá dentro da cadeia. Agora nós nos espantamos só porque o problema, por algumas horas, saiu lá de dentro e foi para as ruas. Se não, nem nos importávamos. (Zero Hora, 13.07.1994, p. 63).

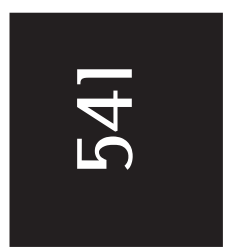

Se, no caso do editorial do Correio do Povo, podíamos observar a crítica de um veículo concorrente à posição assumida por Zero Hora por meio do editorial de Augusto Nunes, já no texto de Sant'Anna, emerge uma crítica interna que aponta veladamente para o cinismo da posição de seu chefe. De qualquer maneira, a visão do inferno construída no discurso do redator-chefe não deixa de aparecer na crônica de Paulo Sant'Anna, com a diferença de que enquanto o primeiro amedronta-se com o transbordamento circunstancial deste para o espaço civilizado da cidade, o segundo quer sublinhar a existência estrutural de um inferno dentro dos presídios, cuja constatação não interessa àqueles que não o vêem cotidianamente:

Se querem saber, ocorrem assassinatos terríveis, estupros, felações, assaltos, escravaturas, presos sem poder dormir durante várias noites seguidas, com medo das agressões e da morte, num verdadeiro inferno, pior que o inferno ameaçado pela Bíblia, porque se sabe que é real e se desenrola junto da sociedade, embora esta finja irritantemente que o desconhece. (Zero Hora, 13/07/1994, p.63). ${ }^{7}$

Por outro lado, enquanto o texto de Nunes criminaliza os órgãos do Estado e vitima a sociedade, o artigo de Sant'Anna opera uma certa inversão de posições ao transformar "bandidos" em sujeitos passivos do crime, e ao conceber a sociedade como um sujeito ativo do crime; mesmo que penalmente esta figura não 
"A noite dos desesperados": motim no Presídio Central em Porto Alegre

exista. É pela omissão que o ser coletivo constrói sua culpa e, numa interpretação menos estrita, podemos dizer que os jornalistas, na fala de Sant'Anna, também constituem o corpo social.

Com certeza, o editorial de Augusto Nunes, $A$ incompetência e o apocalipse, gerou, além dessa crônica sutil de seu colega de redação, desdobramentos menos contidos, como a manifestação do governador do estado em programa de rádio semanal que este mantinha junto à mesma rede de comunicação do jornal Zero Hora. Segundo o periódico, o governador disse na Rádio Gaúcha, no dia 16 de julho, pela manhã: "vocês cometeram muitos excessos a partir de afirmações verdadeiramente absurdas [...] O jornalista Augusto Nunes escreveu um artigo que não tem pé nem cabeça” (Zero Hora, 18.07.1994, p.44). Collares desafiou quatro jornalistas de Zero Hora a fazerem um debate com ele sobre o motim, o que foi rejeitado pela direção da Rede Brasil Sul de Comunicações (RBS) a qual estão vinculados o jornal Zero Hora e a Rádio Gaúcha. ${ }^{8}$

$\mathrm{O}$ jornalista acusado pelo governador responde às críticas na mesma edição que comenta o programa, por meio de outro editorial intitulado $O$ motim foi barrado na festa. No texto, Augusto Nunes ridiculariza a figura de Collares, fazendo ver que na noite do motim o governador comemorava nos salões do Palácio o casamento de sua enteada:

Enquanto os porto-alegrenses ouviam os tiros, o governador ouvia o espocar da champanha. Enquanto a noiva jogava o buquê cobiçado por amigas casadouras, os amotinados jogavam no asfalto um refém ferido à bala. Enquanto um táxi tripulado por bandidos destruía a porta do Hotel Plaza São Rafael e estacionava no hall, Collares administrava o trânsito dos garçons. O anfitrião não foi uma única vez ao seu gabinete de trabalho, para informar-se sobre o que efetivamente ocorria [...] os moradores de Porto Alegre, castigados pelo clima de medo coletivo resultante da cumplicidade entre bandidos e incompetentes, não estão interessados em palavrório. (Zero Hora, 18.07.1994, p. 44). 
Novamente, o jornal, além de emitir opinião, julga. Desta vez, construindo uma identidade entre os fugitivos e o governo, demonstrando para nós que o discurso sobre o crime pode instituir margens muito pouco precisas para definir os "bandidos" em relação ao restante da sociedade. No exemplo desse texto, conclui-se que ao não defender os cidadãos, o governo alia-se aos criminosos, podendo, assim, ser desqualificado pela imprensa.

O então deputado estadual pelo Partido dos Trabalhadores (PT), Marcos Rolim, em artigo publicado em Zero Hora (Sobre a rebelião), realiza um exercício de contemporização ao relativizar culpas e tentar compreender a situação atual do sistema penitenciário gaúcho, reivindicando um tempo mais longo: "[...] posso testemunhar a progressiva degeneração do sistema, resultado que transcende a responsabilidade deste ou daquele governo" (Zero Hora, 13.07.1994, p.17). Mais adiante, chega a reconhecer, como membro da comissão negociadora, o avanço representado pela atitude do governo em garantir uma solução coletiva para o impasse: "Pela primeira vez, o governo do Estado admitiu, por uma conduta concreta, que uma crise aguda fosse enfrentada coletivamente com o concurso dos três poderes, o que confere ao problema a dimensão pública adequada" (Idem). O deputado, contudo, não deixa de lembrar a atitude unilateral da Polícia Civil de realizar a perseguição aos fugitivos, desvinculando-a da posição do governador; diferenciação esta que os editoriais de Zero Hora não fazem. ${ }^{9}$

Além desses vários editoriais e matérias assinadas sobre o motim, o jornal também publicou entrevistas com duas reféns e uma com o suposto líder da rebelião. Simone Munareto Penteado, estagiária de Psicologia na penitenciária e Maria Alzira de Freitas, telefonista do Hospital Penitenciário, revelam nas suas falas um ponto de vista sobre os criminosos que muitas vezes os jornalistas não são capazes de elaborar, já que o campo de visibilidade destes, 
"A noite dos desesperados": motim no Presídio Central em Porto Alegre

por ser mais distanciado, também se torna pouco preciso, abrindo espaço para uma opinião não fundada na experiência. ${ }^{10}$

A entrevista realizada com Simone Penteado (26 anos) traz um título absolutamente incompatível com a experiência narrada pela estudante: Refém de Melara viven 47 horas de terror. Em toda sua fala, percebe-se que a refém não se vê enquanto tal, ou seja, Simone constrói no seu discurso uma identidade com os detentos, mesmo que circunstancial, ao passo que atribui à Polícia a negatividade social geralmente reconhecida aos "verdadeiros" criminosos. Ao lhe perguntarem qual teria sido o pior momento, ela afirma: "Foi quando nos demos conta de que a polícia não cumpriu com o que havia dito. Quando nós nos deparamos com o bloqueio [...] A sensação que a gente teve foi de que em momento nenhum os policiais se preocuparam com a nossa vida" (Zero Hora, 11.07.1994, p.4). Em toda a sua fala, ao longo da entrevista, o "outro" é a Polícia, pois foi esta que transgrediu o acordo estabelecido. Os prisioneiros, no seu ponto de vista, foram vítimas dessa cisão. Ao afirmar que "Em momento nenhum eu senti medo deles [...]", referindo-se aos prisioneiros, a vítima desloca o agente da sua opressão para os supostos representantes da ordem, ratificando a idéia de que na experiência de vida os papéis cumpridos pelos agentes sociais seguem regras que a circunstância prescreve, mais do que aquelas informadas pelos códigos jurídicos ou mesmo pelo ponto de vista dos jornalistas. ${ }^{11}$ A mesma situação pode ser detectada com base na experiência da telefonista. Quando lhe perguntam se os amotinados haviam lhe ameaçado, Maria Alzira responde: "Não. O Fernando e o Pureza até tentaram me acalmar e buscaram café para levantar a minha pressão. Prometeram me libertar porque eu estava tonta" (Zero Hora, 09.07.1994, p.40). E mais adiante: "Antes de eu sair de lá, recebi um abraço do Fernando. O Bicudo, que me levou até o portão, pedia para que eu rezasse por eles, pelos presos e pelos reféns" (Idem).

Anos 90, Porto Alegre, v. 12, n. 21/22, p.535-553, jan./dez. 2005 
Já a entrevista com Dilonei Francisco Melara, "líder" da rebelião, faz ver que as respostas deste detento contrariam as várias premissas contidas explicitamente nas perguntas formuladas. Ele nega o planejamento e coordenação do motim; ele nega um suposto plano de seqüestro de desembargadores; ele nega a existência de uma Falange; ele nega que o motim não tenha dado certo... Melara qualifica a sua prática em função de uma finalidade social que a contém. "Eu roubei para entregar à comunidade carente" (Zero Hora, 17.07.1994, p.44). Ao dar sua última resposta sobre as relações externas ao mundo da prisão estabelecidas pelos detentos, o presidiário constrói em seu discurso uma lógica de inclusão que normalmente negamos ao nos referir a um mundo teoricamente impermeável:

Existe uma força entre a comunidade do sistema que ultrapassa o cárcere. São ascensoristas, vendedores ambulantes, enfermeiras, banqueiros do jogo do bicho, faxineiras, deputados e até senadores que nos ajudam. Estas pessoas nos fazem tudo ver e tudo saber, por isso a execução do Linn será comprovada e a Justiça terá todas as provas para punir os responsáveis. A união dos presos tudo vê e tudo sabe. Por isso não precisamos sequer ter aparelho de TV na cela. Quando você falar com um "chofer" de táxi, ele poderá fazer parte da nossa união (Idem).

Com esse depoimento, será possível afirmar a constituição de um mundo da ordem em contraposição a um mundo da desordem, ou será que estes universos são o resultado de olhares cuja percepção é profundamente histórica e marcada pelo sujeito vedor?

A partir do dia 13 de julho até, pelo menos, o dia 6 de agosto, o jornal publicou dezenas de cartas de leitores no Espaço Livre, onde podemos perceber as formas como a "sociedade" apreende um fato criminoso e, mais do que isto, a reelaboração deste a partir das notícias da imprensa. Antes de qualquer comentário sobre 
"A noite dos desesperados": motim no Presídio Central em Porto Alegre

o seu conteúdo, é fundamental lembrar que desconheço se todas as cartas enviadas foram publicadas e se as cartas publicadas o foram na íntegra ou restaram sumarizadas. Penso também que a motivação que leva alguém a enviar uma carta para uma espécie de "correio do leitor" pode não traduzir a "opinião média" do leitor, se é que podemos utilizar esta expressão. Por outro lado, penso que devemos concordar com Mireille Bossis quando afirma, num ensaio metodológico sobre o uso de cartas, que estas expressam quase sempre sentimentos imediatos e não raciocínios construídos de maneira mais exaustiva: "A carta [...] de maneira característica expressa sentimentos imediatos, emoções, desejos, acompanhados da ambivalência e de contradições mais ou menos pronunciadas dependendo do escritor" (Bossis, 1986, p.67, tradução minha).

Tendo em vista essas ressalvas e também o fato de as cartas não poderem ser extensas, torna-se difícil ao pesquisador abstrair conclusões menos aparentes de sua leitura. De qualquer forma, é possível apontar para alguns indícios reveladores: a maior parte das cartas elogia a posição assumida por Zero Hora (Augusto Nunes) ao questionar a atitude do governo em relação à fuga; outros colocam-se ao lado da posição do governo; alguns criticam "direitos humanos para bandidos"; outros elogiam a ação da Polícia na perseguição aos detentos. Não há como dimensionar com rigor o alcance explicativo dessas cartas, mas da minha leitura ficou um dado significativo. Se a principal imagem fornecida pela cobertura do jornal Zero Hora em relação ao motim era a do medo, do terror, da insegurança, da impotência da sociedade frente ao mal, a correspondência dos leitores, concordem ou não com este ponto de vista, demonstrou uma recepção da notícia cuja reelaboração por meio das cartas utilizou a ironia ou o sarcasmo. Quer dizer, o sentimento foi traduzido discursivamente por meio de um recurso de estilo que não pode, de maneira tranqüila, ser feito equivalente ao discurso do jornal. Vejamos alguns exemplos:

Anos 90, Porto Alegre, v. 12, n. 21/22, p.535-553, jan./dez. 2005 
Direitos humanos para bandidos, "inquisição" para policiais. Que tragédia! Assassinos recebem coletes à prova de balas, os "mocinhos", que devem ter esta peça como parte do uniforme, lutam só com a cara e a coragem. À "corte", festa. Aos criminosos, vida. Aos inocentes, dor e morte. Quanta hipocrisia, meu Deus (Marlize Helena Tartarotti Grezzana, Zero Hora, 13.07.1994, p.62).

Parabéns ao jornalista Augusto Nunes pela merecida resposta ao nosso "ilustre, competente e sensível" governador Alceu Collares (Salim Iessim, Zero Hora, 21.07.1994, p.74).

Pelo que se leu em algumas cartas, escrever bem é a grande virtude do jornalista Augusto Nunes. A partir disto, segundo os leitores, Nunes ganhou qualificação para saber o que é melhor quando está em jogo a segurança da população. Foi-lhe reconhecido também o direito de saber mais sobre os gaúchos do que o governador Alceu Collares. Quando ocorrer um novo motim (espera-se que não ocorra) não esqueçam de consultar o jornalista Augusto Nunes (Eva Silva, Zero Hora, 24.07.1994, p.58).

$\mathrm{Na}$ época que eu era motorista de táxi, num assalto, fui amarrado num mato, meu carro levado e vidas de colegas ceifadas. E na ocasião não apareceu sequer um representante dos direitos (des)humanos em nossa defesa ou de nossas famílias (Dercy Balestrin, Zero Hora, 23.07.1994, p.54).

Em pesquisa de opinião sobre o motim realizada nos dias 13 e 14 de julho com 300 porto-alegrenses e publicada em Zero Hora, concluiu-se que $86 \%$ da população acompanhou os acontecimentos sobre o motim, 59\% sentiu medo com a liberação dos apenados, ao mesmo tempo em que $52 \%$ foi favorável à negociação com os detentos, ainda que apenas 39\% tenham aprovado a decisão da comissão negociadora (cf. Zero Hora, 17.07.1994, p.40). 
"A noite dos desesperados": motim no Presídio Central em Porto Alegre

Em que medida o próprio acompanhamento da cobertura jornalística influenciou as respostas dos pesquisados é um dado que não temos como avaliar. ${ }^{12} \mathrm{~A}$ charge feita por Sampaulo na edição do dia 11 de julho traz a imagem da população fugindo da cidade, ao que um cidadão pergunta a outro: "Apavorados com o frio?". Seu interlocutor responde: "Não!... Com os foragidos do presídio!" (Zero Hora, 11.07.1994, p.17). Seria esse quadro mais um exercício de ironia como aquele das cartas, ou sentimento exato do humorista em relação ao episódio?

O historiador Jean Delumeau (1989, p.22) afirma que "Nada é mais difícil de analisar do que o medo, e a dificuldade aumenta ainda mais quando se trata de passar do individual ao coletivo". Isso nos leva a refletir acerca do quanto existe de real no sentimento de temor declarado na pesquisa aludida e o quanto este sentimento é alimentado pela própria lembrança dos eventos realizada pelo entrevistador poucos dias depois do acontecimento. $\mathrm{O}$ jornal Zero Hora, ao afirmar um dia depois do final da rebelião, que "[...] todos os porto-alegrenses começavam a convalescer dos traumas noturnos" (Zero Hora, 10.07.1994, p.4), contribuiu para construir uma imagem de terror na qual a noite era associada ao mal. Relacionado ao perigo, à cumplicidade, à suspeita, às armadilhas (Delumeau, 1989, p.96-106), o medo da noite foi largamente invocado nas matérias sobre o motim e, mesmo que saibamos que a motivação da fuga noturna tenha-se devido objetivamente a uma possível maior facilidade de efetivar o seu sucesso, sob o ponto de vista dos rebelados, o estabelecimento de relações menos aparentes e simbólicas pelo texto jornalístico foi privilegiado. Quando o sol nasceu, a cura começou a se realizar, mesmo que "A noite dos desesperados" ainda fosse lembrada e transformada em epígrafe das reportagens que o jornal continuaria a fazer ao longo do mês de julho de 1994. 
Cláudio Pereira Elmir

\section{Pós-escrito}

Hoje, já se passaram 10 anos do motim de julho de 1994 no Presídio Central em Porto Alegre. Desde aquele evento, e atravessados 3 governos estaduais (Alceu Collares, Antônio Brito e Olívio Dutra), várias alternativas já foram pensadas para dar solução ao crônico problema da superlotação daquela casa prisional. Falouse, ao final do motim, em descentralizar os lugares de encarceramento em direção à região metropolitana de Porto Alegre a fim de evitar novas mobilizações dos apenados, diluindo com isso a possibilidade de outras fugas. Inúmeras foram as reações adversas das comunidades que vivem nesses lugares. Ao se propor essa difusão de instituições carcerárias de pequeno e médio porte, estava-se, na verdade, dando continuidade ao processo de segregação dos criminosos, na medida em que o Presídio Central deixava de representar o espaço da margem do centro, como fora entendido no início dos anos 1960. Passado quase meio século de sua inauguração, o presídio revela-se pouco distante da visibilidade da boa sociedade. Na medida em que a cidade cresce, torna-se premente para alguns setores do poder público a necessidade de ajustar os espaços de exclusão social, deslocando para mais longe aqueles que foram apartados pelo descumprimento à lei. Propostas surgiram para a venda do Presídio à iniciativa privada, e não seria completamente absurdo supor, em meados da década passada, que se fizesse com esse complexo o mesmo que fora feito com a Casa de Correção no momento de sua desativação no início dos anos 60 do século passado: a sua implosão. Enquanto esse debate prossegue nos poderes que representam a sociedade gaúcha notadamente nos momentos de acirramento dessas crises intermitentes - a casa do Partenon continua sendo diariamente alimentada com novos ingressos, tendo ultrapassado em alguns dias do ano de 1996 a cifra de 2000 apenados, cerca de 200 a mais que o número havido quando da rebelião e mais de 3 vezes a sua capacidade

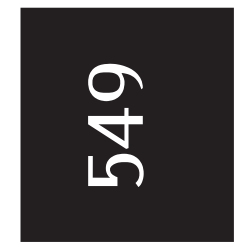


"A noite dos desesperados": motim no Presídio Central em Porto Alegre

inicialmente prevista. Infelizmente, a situação atual sob o governo Germano Rigotto não é muito diferente dessa. Segundo registro feito pelo jornal Zero Hora em janeiro último em Reportagem Especial, contabilizavam-se 3.222 presos na maior cadeia do estado, que já é, segundo o diário, a segunda prisão mais populosa do Brasil (Zero Hora, 23.01.2004, p.4/5).

"The night of the desperates": uproar in Central Penitentiary in Porto Alegre Abstract: By describing the intense journalistic coverage of a penitentiary insurrection which took place in the city of Porto Alegre in July 1994, this paper discusses the contradictions and ambiguities which constitute the discourse on crime. It also shows the unequal relationships established among criminals, the police, political representatives, the elite, journalists, the state executive power, victims, and the city. In short, this article explains the logic that characterizes the relationship between a criminal manifestation and its reporting in printed journals. The press withdraws from the simple informative description of facts, since subjectivity is one of its major characteristics which regulate the journalistic text construction.

Keywords: Porto Alegre. Central Penitentiary. Insurrection. Journalistic coverage. Zero Hora newspaper.

\section{Notas}

${ }^{1}$ Este texto, com pequenas alterações, compõe a primeira parte da Introdução de minha dissertação de mestrado, defendida em outubro de 1996, junto ao Programa de Pós-Graduação em História da UFRGS (Elmir, 1996, p.1-15). Uma versão resumida foi apresentada, sob os auspícios da UNISINOS, no XVIII Simpósio Nacional de História, promovido pela Associação Nacional de História (ANPUH) em julho de 1995 em Recife.

${ }^{2}$ José Rafael Rosito Coiro e Diego Casagrande publicaram, três anos após o motim, um relato minucioso das circunstâncias que envolveram aquele acontecimento. Dizem os autores na Introdução de seu livro: “[...] nosso objetivo restringe-se aos fatos, como se desenrolaram desde o primeiro até o último minuto, e o pânico e terror que os convictos do Presídio Central instalaram em Porto Alegre, por longas 48 horas. [...] o que foi aqui descrito se baseia em mais de 30 entrevistas com autoridades, com vítimas, com os amotinados e com testemunhas. Em nossas mãos, mais de 80 horas de gravações, bem como relatórios e inquéritos oficiais garantem a veracidade dos fatos descritos" (Coiro; Casagrande, 1997, p.18-19). Em

Anos 90, Porto Alegre, v. 12, n. 21/22, p.535-553, jan./dez. 2005 


\section{Cláudio Pereira Elmir}

seu livro, não encontramos qualquer avaliação sobre a cobertura feita pelo jornal Zero Hora.

${ }^{3}$ De qualquer maneira, é importante assinalar que nenhuma das duas principais revistas informativas semanais com ampla circulação nacional - Veja e Isto É - dedicou sequer uma nota sobre esse acontecimento nas edições das semanas dos dias 13,20 e 27 de julho.

${ }^{4} \mathrm{Na}$ segunda-feira, dia 11 de julho, o Governador Alceu Collares toma a decisão, sugerida pela comissão negociadora, de indenizar "[...] as pessoas que sofreram danos morais ou de saúde durante a perseguição aos fugitivos" (Zero Hora, 12.07.1994, p.46); o que pode ser entendido como um reconhecimento, em alguma medida, da responsabilidade do Estado pela atitude tomada pela Polícia Civil.

${ }^{5}$ Em depoimento dado pelo atual proprietário do Correio do Povo, Renato Bastos Ribeiro, ao jornalista Walter Galvani, percebe-se claramente que a "crônica policial" não é prioritária nos interesses editoriais do jornal: "A intenção continua sendo o equilíbrio da informação e da opinião, por uma questão filosófica, não dar destaques a catástrofes, ao negativo, ao crime. E estamos trabalhando em cima de um noticiário positivo, que crie ânimo, vontade nas pessoas de realmente trabalhar em favor da liberdade e da livre iniciativa" (apud Galvani, 1994, p.513).

${ }^{6}$ Em outro editorial, sob o título Superlotação de Presídios, o jornal anuncia que a solução para o problema penitenciário reside no incremento material dos presídios que possibilite um real aumento de vagas, além da ocupação dos detentos em atividades produtivas: "O ócio permanece péssimo conselheiro, transformará as horas vazias em incessante perpassar de idéias sinistras. A solução do problema está em aumentar a capacidade correcional. Tudo o mais é fantasia" (Correio do Povo, 16.07.1994, p. 4).

${ }^{7}$ Três meses depois, o jornal publica outro editorial que discute o crescimento da criminalidade nos Estados Unidos e no Brasil e volta a referir a figura do inferno, parecendo uma réplica à crônica de Paulo Sant'Anna: "Se a vida é um inferno no interior destas casas de detenção malcuidadas, fora delas não está muito melhor" (Zero Hora, 14.10.1994).

${ }^{8}$ No dia 28 de julho, o jornal Zero Hora publica carta enviada pelo governador à direção da RBS, na qual ele manifesta sua contrariedade em relação ao tratamento que o grupo tem dispensado à sua pessoa e ao seu governo, pedindo um "direito de resposta" por meio de um debate com quatro jornalistas, entre eles Augusto Nunes. Diz, a certa altura: "Sinto-me, ultimamente, agredido por alguns setores da RBS e gostaria de expor aquilo que a empresa omite aos seus leitores e ouvintes, como a revolução no campo da educação, o saneamento das finanças estaduais, a unificação do sistema financeiro e as, aproximadamente, 7 mil obras que se está deixando em quatro anos de governo" (Zero Hora, 28.07.1994, p.60). Ao lado, o jornal publica a resposta da RBS, na qual o Diretor-Presidente do grupo, Nelson

Anos 90, Porto Alegre, v. 12, n. 21/22, p.535-553, jan./dez. 2005 
"A noite dos desesperados": motim no Presídio Central em Porto Alegre

Sirotsky argumenta a impossibilidade desse debate acontecer, por entender não ser esta a função de jornalistas e por julgar que o governador já dispõe de espaço regular em uma rádio do grupo para exercer a defesa de seus pontos de vista. Com certeza, a cobertura realizada pelo jornal sobre o motim contribuiu para catalisar este descontentamento do primeiro mandatário do estado.

${ }^{9}$ Não posso deixar de mencionar que o mesmo deputado elaborou um Relatório sobre o motim, publicado pela Assembléia Legislativa, por intermédio de seu gabinete, e que traz uma avaliação extremamente lúcida de todo o processo de insurgência no presídio até o seu desfecho. Ao final, deixa entrever uma crítica pela qual a imprensa, mesmo não citada explicitamente, tem espaço: "Aos que se dedicam a estimular os preconceitos, aos que subsistem promovendo o senso comum, aos que transformam sua própria ignorância em 'opinião', aos que, por decorrência, estimulam a violência, dedico este relatório. Minha atividade seria de todo desnecessária se eles não tivessem poder" (Rolim, 1994). No Seminário Imprensa, Polícia e Motim, promovido pela Faculdade de Biblioteconomia e Comunicação (FABICO) da UFRGS nos dias 19 e 20 de outubro de 1994, o delegado de polícia Alexandre Vieira, que participou do desfecho da fuga dos detentos, afirmou que não houve uma ordem no sentido da perseguição aos fugitivos, tendo ocorrido apenas um "acompanhamento à distância" ou um "monitoramento" da saída dos presos. Em entrevista concedida a Rafael Coiro e Diego Casagrande, o delegado novamente nega a ordem de perseguição (v. Coiro; Casagrande, 1997, p.75-76).

${ }^{10}$ É importante lembrar, neste sentido, que não consta que os editorialistas do jornal Zero Hora tenham participado pessoalmente do processo de amotinamento e de fuga. Apenas os repórteres do jornal viveram aquela situação, tendo servido, talvez, seus relatos e descrições nas matérias não assinadas como referências para a escritura dos editoriais. Um dos editores de Polícia, Humberto Trezzi, declarou no Seminário referido na nota anterior, que passou cerca de 40 horas dentro da Redação do jornal coordenando o trabalho de toda a equipe; logo, não participando diretamente dos eventos.

${ }^{11}$ É notável aqui a contradição entre a prática jornalística de Zero Hora e as prescrições feitas aos seus jornalistas no Manual de ética, redação e estilo do mesmo jornal, como pode ser constatado neste trecho: "Os títulos são o cartão de visita de uma notícia ou reportagem. Elabore-os com cuidado extremado para que sejam a expressão fiel do texto" (Nunes, 1994, p.71).

${ }^{12}$ De qualquer maneira, é importante lembrar que essas pesquisas nem sempre expressam o sentimento da população como um todo sobre o objeto do questionamento: "Todo sociólogo conhece a relatividade das pesquisas de opinião. Ele sabe o quanto a atitude do público entrevistado no calor da hora é esporádica e superficial. Basta informar a opinião pública de alguma horrível maldade e, em

Anos 90, Porto Alegre, v. 12, n. 21/22, p.535-553, jan./dez. 2005 


\section{Cláudio Pereira Elmir}

seguida, sondá-la no momento adequado para obter o resultado esperado" (Chesnais, 1981, p.435, trad. Flávio Heinz).

\section{Referências}

BOSSIS, Mireille. Methodological journeys through correspondences. Yale French Studies, New Haven, n.71, p.63-75, 1986.

CHESNAIS, Jean-Claude. Histoire de la violence en Occident de 1800 à nos jours. Paris: Robert Laffont, 1981.

COIRO, José Rafael Rosito; CASAGRANDE, Diego. Porto Alegre: 48 horas sob terror. Melara e a rebelião no Hospital Penitenciário. Porto Alegre: Artes e Ofícios, 1997.

DELUMEAU, Jean. História do medo no Ocidente (1300-1800). Uma cidade sitiada. São Paulo: Companhia das Letras, 1989.

ELMIR, Cláudio Pereira. O crime da Última Hora. Porto Alegre na passagem dos anos cinqüenta. 1996. Dissertação (Mestrado em História) - Programa de PósGraduação em História, Universidade Federal do Rio Grande do Sul, Porto Alegre, 1996.

GALVANI, Walter. Um século de poder, os bastidores da Caldas Júnior. Porto Alegre: Mercado Aberto, 1994.

JESUS, Damásio Evangelista de. Direito Penal. 15. ed. São Paulo: Saraiva, 1991. V. I. Parte Geral.

NUNES, Augusto. Zero Hora. Manual de ética, redação e estilo. Porto Alegre: L\&PM, 1994.

ROLIM, Marcos. Relatório sobre o motim. Porto Alegre: Assembléia Legislativa do Estado do Rio Grande do Sul, 1994. 16p.

Recebido em 22/11/2004.

Aprovado em 15/07/2005. 